\title{
VET teachers between school and working life: boundary processes enabling continuing professional development
}

\section{Per Andersson \& Susanne Köpsén}

To cite this article: Per Andersson \& Susanne Köpsén (2019): VET teachers between school and working life: boundary processes enabling continuing professional development, Journal of Education and Work, DOI: 10.1080/13639080.2019.1673888

To link to this article: https://doi.org/10.1080/13639080.2019.1673888

(c) 2019 The Author(s). Published by Informa UK Limited, trading as Taylor \& Francis Group.

\section{曲 Published online: 12 Oct 2019.}

Submit your article to this journal $\widetilde{ }$

$$
\text { Џll Article views: } 49
$$

Q View related articles ¿

$$
\text { View Crossmark data } \nearrow
$$




\title{
VET teachers between school and working life: boundary processes enabling continuing professional development
}

\author{
Per Andersson (iD and Susanne Köpsén \\ Department of Behavioural Sciences and Learning, Linköping University, Linköping, Sweden
}

\begin{abstract}
Changes in working life require development in vocational education and training (VET) to retain industrial currency. VET teachers are key actors in VET, and their continuing professional development (CPD) in vocational subjects is central to the currency of VET. This study is situated in Sweden, with a mainly school-based VET system where VET teachers have the main responsibility for students' school-based and workplace learning, and they typically have a background in an initial occupation which they now teach their students. The study applies a situated learning perspective, with a particular focus on boundary processes between VET schools and working life, and how the modes of identification of engagement, imagination, and alignment are enacted and influence the identity formation and CPD of VET teachers. The findings are based on interviews with 30 Swedish VET teachers. The qualitative study shows how different forms of boundary encounter between VET teachers and working life, brokering of occupational knowledge, and reconstruction of occupational practices at schools provide opportunities for teachers' CPD and influencing vocational teaching. It is important for the quality of VET teachers' CPD to include and integrate the different modes of identification, to allow for updating of different aspects of the occupational identity.
\end{abstract}

\section{ARTICLE HISTORY}

Received 14 January 2019

Accepted 25 September 2019

\section{KEYWORDS}

Boundary process; initial occupation; VET teacher identity; professional development

\section{Introduction}

Working life changes rapidly when new occupations arise and old ones change. There are new demands in terms of occupational knowledge and skills inherent in new technology. Consequently, there have been and are demands on the development of vocational education and training (VET) to adjust to current working life and occupational practices (Cedefop 2009, 2018a). This development includes demands on updating VET teachers' subject knowledge. The teachers need occupational knowledge and skills with high currency to teach and prepare their students for employability. However, there are constraints concerning the opportunities for VET teachers to retain such knowledge and skills (Fejes and Köpsén 2014). This article focuses on Swedish VET teachers' opportunities and activities for continuing professional development (CPD) concerning occupational knowledge and skills as part of their work as teachers, and what this vocational learning means for the continuing formation of the VET teacher identity.

Interplay between working life and school is essential within VET, and VET teachers have a central role as the link between school and working life. VET teachers' updating of their knowledge to retain industrial knowledge also requires interaction with and presence in working life where the occupational knowledge they teach is situated. Therefore, we employ a theoretical perspective of situated learning (e.g. Wenger 1998) where the interplay between working life and school, and VET teachers' 
interactions here, are seen as boundary processes between these practices. In this article, we specifically investigate these processes as opportunities and methods for VET teachers' CPD and for the development of their teaching.

We see the VET teacher identity as dual, an occupational identity and a teacher identity, being shaped through participation in and boundary crossings between different communities of practice: work in their initial occupational practice, teaching in the practice of VET, and learning through teacher training (Farnsworth and Higham 2012; Fejes and Köpsén 2014). We consider the dual VET teacher identity to be an ongoing balancing act and identity formation, mainly due to VET teachers' boundary processes and boundary crossings within a landscape of communities of practice related to their prior, initial occupation and their teaching.

VET is organised differently in different countries (Cedefop 2018b). Some systems are solely or mainly workplace-based, while other countries employ a dual or a mainly school-based system, in the latter case typically including periods of workplace learning (Deissinger et al. 2013; Dobbins and Busemeyer 2015). The different systems mean different opportunities for cooperation between school and working life, but also different teacher responsibilities concerning students' workplace learning. Nevertheless, the boundary-crossing character of the work as a VET teacher is important for good teaching (Smith and Yasukawa 2017), and regardless of differences between contexts, there are basic similarities concerning the demands placed on teachers' competence in occupational teaching subjects, and the need for links to working life for the currency of VET.

The present study is situated in upper-secondary level VET in Sweden. Here, VET is mainly schoolbased, but the three-year programmes include at least 15 weeks of workplace learning. There is also an alternative track of apprenticeship training with at least $50 \%$ workplace learning. Twelve national VET programmes cover a broad spectrum of occupations, such as healthcare, building and construction, and vehicle maintenance. Corresponding VET courses are taught in upper-secondary level adult education, but with shorter programmes that do not include the general subjects which are compulsory in upper-secondary school programmes. VET teachers have the main responsibility for the vocational learning processes of students and apprentices, including workplace learning, even if there are supervisors in the workplaces. Furthermore, these teachers typically have a background in an initial occupation in which they are now teaching and training their students, but most VET teachers have left that occupation and are employed full time as teachers. Thus, there is an evident need for VET teachers' boundary processes between school and working life, to fulfil their responsibilities in relation to the students, and to develop their teaching - but also to keep the industrial currency of their own occupational knowledge and skills which are the contents of their teaching.

In other words, these boundary processes are important for VET teachers' own workplace learning in their work as teachers. This study is part of a larger project concerning VET teachers' CPD related to their initial occupations (Andersson, Hellgren, and Köpsén 2018; Andersson and Köpsén 2015, 2018; Köpsén and Andersson 2017, 2018). In this project, we have seen that institutional conditions in VET schools are influencing teachers' opportunities for development. The employer, the VET institution, has the formal responsibility for teachers' CPD. However, the contents of organised CPD opportunities are not regulated, and the focus on the initial occupations is limited. This means that such CPD in practice mainly becomes a responsibility of the individual VET teacher (Andersson, Hellgren, and Köpsén 2018; Fejes and Köpsén 2014). Therefore, the focus here is on the boundary processes between school and working life, and how the school-working life interplay involves VET teachers and provides opportunities for updating of occupational competence and reshaping of occupational identity.

\section{VET teachers' CPD in the initial occupation and their dual identity}

Studies of VET teachers' CPD are sparse (de Rooij, in Parsons et al. 2009, 92) and focus mainly on teaching competence (Bound 2011; Messmann and Mulder 2011). But in an Australian study of views among students and teachers concerning what a 'good VET teacher' is, both categories highlighted 
teaching skills as well as expertise and experience from industry as being important (Smith and Yasukawa 2017), which indicated that VET teachers' boundary processes are important for the quality of teaching. The present article contributes to this research area, with a focus on CPD related to the vocational subject and industrial currency. Even if research projects with this focus are limited, there are some relevant studies.

Broad $(2013,2015,2016)$ studied CPD to retain and develop occupational knowledge among teachers at English further education colleges. Reading books, journals, and online material turned out to be the most common of 12 pre-defined CPD activities among these teachers. Different activities that provide CPD experiences were included, such as practising, peer observations, shadowing, students' workplace learning (placements), involvement with professional bodies, educational trips, and inviting guest speakers, as well as attending courses and workshops (Broad 2016). Broad (2013) identified three key drivers for CPD: the passion for the subject/occupation, to maintain occupational currency, and to improve teaching and students' learning. Teachers work hard to achieve these results, but the main barrier for professional development seemed to be lacking or 'impoverished' networks - a consequence of teachers' workload and lack of time (Broad 2015).

Lloyd and Payne (2012) showed how conditions of employment influenced the opportunities to maintain the currency of competence. Part-time employment as a teacher could, for example, mean an opportunity to keep on working in the initial occupation. Institutional structures and support from management are other factors influencing VET teachers' motivation and possibilities to move between the practices of school and working life (Frisk 2014). Fejes and Köpsén (2014) also identified various constraints for these teachers' participation in working life, and those who did not maintain the currency of their occupational competence were not able to teach the advanced courses.

Brennan Kemmis and Green (2013) showed a duality of identity in a study of Australian VET teachers' conceptions of their pedagogy (cf. Fejes and Köpsén 2014). These teachers showed a strong connection to the workplaces and the vocations, which could mean tensions in relation to other categories of teachers who were not based in another, initial occupation. Farnsworth and Higham (2012) presented a similar analysis of the VET teacher identity in a Canadian study, where they discussed how the professional identity of VET teachers is modulated and hybridised in connecting experiences from two communities of practice - the practice of the initial vocation, and the practice of VET.

In the Nordic context, Vähäsantanen and Eteläpelto (2009) analysed VET teachers' experiences of a reform for more interplay between schools and workplaces, and what this meant for their professional identity. The teachers saw increased cooperation as desirable, but their attitudes towards the reform still differed. Some saw more problems in the increased boundary-crossings and other changes in the teacher work that would be a result of the reform, while others were more enthusiastic about their work with students' workplace learning. Vähäsantanen, Saarinen, and Eteläpelto (2009) also emphasise how boundary crossings between school and working life can be of value for VET teachers' professional development, and for the development of teaching in alignment with working life. However, the authors describe how the personal contribution can be huge, when teachers use their free time to develop these relationships.

As mentioned, the present study is part of a larger research project in Sweden. Here, an analysis of a national initiative to stimulate VET teachers' workplace-based CPD in the initial occupation showed that the vocational area and the geographical region in which the teachers are employed influenced participation. Teachers in technology and construction were underrepresented among the participants, but with a comparably higher participation rate in industry arrangements among construction teachers. Teachers from highly populated municipalities were overrepresented, and the type of municipality was the strongest predictor of recurrent participation (Andersson and Köpsén 2015; Köpsén and Andersson 2017).

These studies raised new questions, resulting in a survey study of participation in various CPD activities among VET teachers (Andersson, Hellgren, and Köpsén 2018; Andersson and Köpsén 2018). It showed that reading was the most common CPD activity (cf. Broad 2016), and reading together 
with work in the initial occupation were also the activities where the variation in performing them could be explained to the highest degree. The survey showed that $86 \%$ of Swedish VET teachers make study visits to workplaces together with their students at least yearly, $81 \%$ perform the task of managing students' workplace learning, and $60 \%$ are involved in work in their initial occupations, and the teachers perceive this as important for their relationships with working life. The perceived values created in terms of occupational knowledge and networking, and for teaching provided by teachers were significantly higher among VET teachers who had actually performed the activities on a regular basis, as compared to those who had not (Andersson and Köpsén 2018). The most important factors for the perceived values, in addition to actually having performed the activity, are teachers' sex and individual, dispositional drivers (Andersson, Hellgren, and Köpsén 2018).

To find out more about VET teachers' professional development and relationships with working life, an interview study was conducted. An initial analysis identified conditions and potentials for teachers' updating of occupational competence in connection with students' workplace learning (Köpsén and Andersson 2018). The qualitative findings show that VET teachers' management of their students' workplace learning offers potentials for updating occupational competence. However, the way in which the VET teachers choose to undertake the tasks in connection with students' workplace learning is highly significant. The frequency and duration of these teachers' workplace visits or engagement in day-to-day work and interactions with the professionals in the workplace affect their ability to acquire current occupational identity. The more the teacher participates authentically in work, the higher the potential for CPD, but structural conditions of school practices influence the possibilities to visit or engage in the workplaces. This initial analysis is followed up in the present article, where we include boundary processes between school and working life in a broader sense.

\section{Theoretical perspective}

The occupational knowledge that VET teachers teach is situated in working life, they have a dual vocational teacher identity, and their interactions with and presence in working life are essential for their CPD. Therefore, a theoretical perspective focusing on situated learning, identity formation and boundary processes has been considered appropriate (Akkerman and Bruining 2016; Farnsworth and Higham 2012; Fejes and Köpsén 2014; Köpsén and Andersson 2018; Lave and Wenger 1991; Wenger 1998) to investigate how the school-working life interplay, seen as different boundary processes, involve VET teachers and their updating of occupational competence. There is criticism of this perspective, discussed, e.g. by Farnsworth, Kleanthous, and Wenger-Trayner (2016). However, we have found the social theory of learning and work of Wenger, focusing situated knowledge and learning and processes between different communities of practice, suitable for our study and analysis.

An occupational identity develops through participation in work and social interaction with other members of an occupational practice (Wenger 1998). The basic prerequisites for participation and the development of an identity are access to the community of practice and recognition as a legitimate member of the community (Lave and Wenger 1991), with its specific regime of competence (Wenger-Trayner and Wenger-Trayner 2015). Then, having developed an identity means being recognised as competent enough to fully engage in the joint enterprise, including skilfully performing the tasks, knowing how to communicate and cooperate with other members, and using the repertoire of resources (Wenger 1998).

Since learning is an aspect of participation, different activities or 'modes of identification' influence the formation of an identity (Wenger 1998; Wenger-Trayner and Wenger-Trayner 2015). The processes of engagement include the access to and involvement in the mutual actions, communications and relations as well as to the shared repertoire of resources. Two other modes of identification are about opening the horizon and looking beyond the everyday work. Imagination means creating images of the work and seeing connections through time and space, such as locating the engagement in a wider context and sharing stories with others, and exploring other ways of working and relating to others. Processes of alignment are about coordinating activities and 
perspectives in order to fit within broader structures and contribute to broader enterprises. These activities require boundary processes and connections, individuals with multi-membership, and sharable artefacts.

A community of practice is not stable but changing, and ongoing participation is needed to maintain an identity including full membership of the community of practice (Wenger 1998). Thus, to maintain an occupational identity with industrial currency requires continuing participation including processes of engagement, imagination and alignment, in the occupational practice.

As mentioned, we argue for the duality of VET teacher identity (Fejes and Köpsén 2014). VET teachers need to be competent at teaching as well as participating in today's occupational practice related to their initial occupation and the vocational subject which they teach (Farnsworth and Higham 2012; Köpsén 2014; Robson, Bailey, and Larkin 2004; Smith and Yasukawa 2017). It is through interplay between different communities in a landscape of practice, so-called boundary processes, that individuals learn, develop a nexus of identities, and become knowledgeable in relationship to this landscape (Wenger-Trayner and Wenger-Trayner 2015). Boundary processes are common in vocational education (Berner 2010; Tanggaard 2007), and through these processes, both students and teachers learn. The teachers shape their vocational teacher identity as a nexus of a teacher identity and an occupational identity (Fejes and Köpsén 2014). They cross the boundaries when they become VET teachers, but they also benefit from ongoing boundary processes when working as teachers, which is essential for them to remain competent concerning their occupational identity as well as in teaching the vocational subject.

Boundary processes between communities of practice can take place through boundary encounters with different purposes, involving brokers on different levels such as individuals, groups or practices (Akkerman and Bruining 2016). Boundary encounters can be permanent or temporary, such as meetings, visits or conferences, and involve different processes of participation (Wenger 1998). The boundary crossings of VET teachers mean temporary boundary encounters with individuals or groups of individuals representing workplaces and other significant communities of practice. The teachers can also be involved in boundary encounters in opening up the boundary of the practice of school to let brokers import occupational knowledge from other practices into the practice of teaching.

Another type of boundary process in school-based VET is reconstruction (Berner 2010). Here, workplace experiences are reconstructed in the school practice. Berner highlights the use of instruction forms similar to those found in work-based apprenticeship training, and the reconstitution of factory life in the workshop at school. Such reconstruction means efforts for alignment between school and industry, which allow students to imagine what factory life is like, and to engage in factory-like work practices.

In this study, we analyse VET teachers' descriptions of different modes of identification through boundary encounters in external practices as well as in the practice of school, with potentials for learning and updating their occupational identity. More specifically, we are interested in how boundary encounters may offer opportunities for vocational teachers' formation of a current occupational identity and, furthermore, influence their teaching of the vocational subject, a work task that is a part of the teacher identity.

\section{Aim and research questions}

The aim of this study is to examine the interplay between school and working life, and how this may involve VET teachers and their updating of occupational competence and re-shaping of the VET teacher identity. The research questions are:

(1) How are boundary processes between the community of school and other communities of practice in working life enacted?

(2) In what way can these boundary processes enable VET teachers' learning of an up-to-date occupational identity?

(3) What influences do these boundary processes have on vocational teaching? 


\section{Method}

This article presents a qualitative study of VET teachers' CPD with a focus on learning opportunities inherent in boundary processes between school and working life.

\section{Data}

The findings are based on semi-structured interviews with 30 VET teachers from all 12 national VET programmes in Sweden, including upper-secondary school as well as adult education. Eleven female and 19 male teachers were interviewed, a distribution that corresponds to the population of VET teachers at Swedish upper-secondary schools (Swedish National Agency for Education 2017), teaching at schools in both small and large towns.

The VET teachers described their contacts and relationships with working life, CPD in the vocational subject, conditions for work-life connections, and conditions for professional development. This article presents results obtained from, in particular, the answers concerning relationships with working life, and what these relationships mean for the professional development and for the development of teaching. All interviews were conducted in Swedish and transcribed verbatim, and the quotations used to illustrate the findings were translated into English. For each quotation, we have indicated the initial occupation of the VET teacher. When there is more than one teacher with the same initial occupation they are marked no. 1 and no. 2.

The study follows the guidelines from the Swedish Research Council (2017) concerning good research practice, including such matters as consent, confidentiality, information provided to interviewees, and the use of data.

\section{Analysis}

We used the NVivo software for the qualitative analysis of the transcribed interviews. We initially identified the parts of the data relevant to teachers' relationships with working life. In the following deductive coding and analysis of the data, we identified expressions of different types of boundary process and opportunities for learning, against the background of our theoretical perspective and concepts (Wenger 1998). The key concepts of boundary encounters, brokers/brokering and learning of identity were used when answering the research questions about the VET teachers' enactment of boundary processes and how these processes involve teachers' learning and teaching.

\section{Enactment of boundary processes}

How are boundary processes between the community of school and other communities of practice in working life enacted? Opportunities for VET teachers' updating of industrial currency and continuing formation of the VET teacher identity are identified in three forms of boundary process, in the interplay between school and other communities of practice in working life related to VET: VET teachers' boundary crossings through various boundary encounters, opening up the community of school for the engagement of brokers and the transfer of occupational knowledge into the practice of VET teaching, and reconstruction of work practices within the practice of the VET school. According to the interviewees, the boundary encounters and brokering are enacted in different ways involving different modes of identification and thus different opportunities for learning. VET teachers' learning of current occupational knowledge, and their re-formation of the VET teacher identity, are possible in different ways in relation to these forms of boundary encounter, brokering, and reconstruction. 


\section{Boundary encounters between VET teachers and the occupational practice}

VET teachers are participating in different kinds of boundary encounter with the occupational practice, here at workplaces outside school.

\section{Short one-to-one visits}

The first type of encounter is a short visit to a workplace, where the VET teacher typically meets an employee who is supervising a VET student. These encounters are often one-to-one meetings taking place outside the daily work at the workplace. Another type of short visit is when the teacher meets staff at a local supplier of materials. In the following example, a building and construction teacher describes his visits to the local building-material business.

... would new types of board come that we have to use, then they tell me at the building material business that 'no, you are not allowed to use this one' [...] and I am at the business rather often and talk with them, so there I get quite a lot of information ... (Construction worker and VET teacher)

In terms of teachers' learning, these short one-to-one visits are primarily a matter of alignment, a process of coordination between VET and workplace concerning students' workplace learning, or the development of materials. Limited imagination about the work practice could be possible as a by-product, through the conversation with the employee, even if the teacher does not see the actual work processes.

\section{Visiting the worksite}

The second type of encounter includes more extensive visits to workplaces and the actual worksites, with the opportunity to see activities and talk to employees/colleagues working there. These visits are also typically related to students' workplace learning, and are thus primarily a matter of alignment between school and worksite concerning this part of VET.

In addition to alignment, the visits to worksites give opportunities for imagination, where the VET teacher sees current work-life practices, and also possibly talks to industry colleagues concerning their work. The visit could be a by-product of the task of meeting the supervisor and the student for a conversation concerning the workplace learning.

Now a three-partite conversation should take place at the workplace at least once in every period of work-based learning, which means that I have to go to all the restaurants that we send [students] to. [...] And then you always have a short walk-around to have a look ... (Chef and VET teacher)

When it comes to the VET teacher's learning, the walk-around provides an opportunity for imagination, but the activity as a whole is primarily focused on alignment concerning students' workplace learning. The following teacher describes a two-step process of imagination: Firstly, to see and get information about material, and secondly to see workers using it in the construction site.

I get information about new material when I visit a supplier, but if I visit a construction site, then I will also see them using the new stuff. (Plumber and VET teacher)

There are also VET teachers who actively and consciously prepare for and use the visits to maintain their industrial currency.

... I don't just ask about the students, I also use some of that time to ask how things are going in the industry. What's new? I draw up a list before the visit. I want to be updated about the industry. (Salesman and VET teacher)

Teachers could also carry out visits to worksites independently of their work with students' workplace learning. As mentioned, it is common for Swedish VET teachers to conduct study visits with their students, but teachers could also carry out visits by themselves. The following teacher from the vehicle and transport programme describes a visit to a logistics terminal.

It could be enough to go to a [logistics] terminal and simply watch how it works with trucks and the logistics. When cargo trucks come in at night, and is unloaded and so on. How it works. It becomes a conglomeration of 
drivers who run with trucks all the time, and then just 'Bam!' and then it's empty. No-one there any longer when the cargo trucks leave. (Truck driver and VET teacher)

These study visits involve imagination through observation of interaction, like during workplace learning-related visits but unlike the types of imagination based on brokers providing information and telling stories that create an image of the work processes. Such brokering processes will be discussed below.

\section{Participating in work}

The next type of boundary encounter is when VET teachers participate in occupational practice (workplaces), doing the work of their initial occupations. This is another mode of identification engagement, which includes teacher's access to and involvement in the actions, communications and relationships at the workplace as well as to the shared repertoire of resources. This form of authentic participation entails a wealth of potential for learning and updating an occupational identity with industrial currency. This could take place in different ways. Participating in work could be done as part of the VET teacher work or as an organised CPD activity. However, VET teachers also do work in their initial occupations outside the teacher position. In the latter case, the learning dimension could be more or less explicit, with a mix of motives - such as retaining the industrial currency needed for VET teaching or to be able to go back to the initial occupation, or earning some extra money, or earning money by doing things oneself (at home) instead of paying someone else.

And then when you have had a summer holiday earlier for ten weeks, then I have been working maybe four of those weeks. [...] I have been returning to work for a month every summer [...] I feel rather up-dated as I have chosen to work in homecare [...], we do a lot of work with elderly health in the healthcare programme ... (Nurse and VET teacher no. 1)

\section{Production outside school - participating in work with the students}

Another type of engagement in work outside school is when the VET teacher uses external contracts to involve students in authentic work tasks, where they are producing goods and services for actual customers in an authentic work practice outside school. This is similar to the specific workplacelearning parts of VET with a local supervisor. The difference here is that it is a group of students who cross the boundary and go from school to an authentic practice and engage in work together with and under the supervision of their teacher from school. The following VET teacher describes how this activity is important not only in terms of engagement but also for alignment with current practice in his trade and thus becomes a learning opportunity for him as a teacher.

\footnotetext{
When I use teaching hours for being out there with students and work at fairs, I am also in touch with the trade where I was working before. And this is valuable for me as it is constantly changing, and if I were not out working with students or visiting fairs myself and being interested in fair activities, then I would refer to how it was earlier, in my lessons. I want to talk about how it is now. (Team leader in hotel and conference, and VET teacher)
}

\section{Boundary encounters: VET teachers' relationships with industry}

The interaction of VET teachers with industry and other professionals is often organised in specific industrial arrangements. This means participation and learning in boundary encounters between professionals, where the teachers could retain relationships, belonging, professional language, etc. These arrangements mainly involve identification or learning in terms of imagination and alignment. However, if the boundary encounter is arranged as a course, focussing on training and practising the use of new tools, machines, etc., there could be learning through engagement and involvement, even if it is limited to specific skills - it is not a matter of engagement in the everyday worksite practice. 


\section{Industry arrangements and courses}

The first type of activity here is the industry arrangement organised for networking and professional development. These are typically organised by the industries. Here we include fairs targeting a whole industry, where VET teachers meet and interact mainly with colleagues from their initial occupation, as well as suppliers of tools, materials, etc. These fairs are most important for many VET teachers.

We meet suppliers at the fairs ... fairs are what I think is the most important ... What's new? We will never learn if we stay at school, but we have to leave the school actively to see what's happening. (Chef and VET teacher)

A second type of activity is targeting the VET teachers in a specific industry, who meet colleagues from the same VET programme at other schools as well as from industry. For example, one teacher describes how the bakery association organises a conference for bakery teachers. This conference embraces both parts of the dual identity of their VET teachers, covering teaching-related learning as well as learning about industry. This boundary encounter provides imagination and alignment in relation both to the bakery industry and to other bakery schools/programmes.

Then we talk about a lot of different things that the industry has passed over to the bakery association, about what we actually teach at the schools. [...] On the second day we have vocational training, and then it is those who compete in the bakery and pastry national teams, we look at trends and traditions and compare [...], then it is the occupational competence. So it is the [teacher] profession, and the occupational competence, that is how we separate it. (Baker and pastry cook, and VET teacher)

\section{Internet-based networking}

Social media has meant new opportunities for informal networking. This is particularly highlighted by teachers from less common occupations, or with specialised work tasks. They are able to network and keep up-to-date, in cooperation with colleagues around the country. The following teacher from the vehicle programme has the task of organising driving tests for students. There are only a few vehicle teachers with this task, which means that there is a need for remote networking.

\footnotetext{
I belong to some groups myself [...] for those who create the driving tests, where we bring up different things and discuss problems. How you could solve problems with documentation, and such things. (Truck driver and VET teacher)
}

Another example comes from the handicraft programme. This VET teacher is a goldsmith, participating in a network for practising goldsmiths, where he finds knowledge that helps him to stay up-todate in this craft. Such networks provide imagination about and alignment with current practices:

And that is very good, because all questions about the vocation, from pricing to solving certain handicraft problems, turn up there. [...] So there you get involved and write questions. And working as a goldsmith is quite a small occupation ... (Goldsmith and VET teacher)

\section{Skills competitions}

Qualified VET students, and professionals, meet and compete in skills competitions. However, a competition is also a forum for the VET teachers. They are supporting their students in preparing for competitions, but they are also involved in the arrangements, for example, as judges. Being a judge means being involved in a boundary encounter with colleagues in the industry, and seeing and discussing - imagining and aligning with - current skills requirements and developments in the area. It is also an arena for networking, with the opportunity to establish contacts with qualified experts who later could be invited to the VET school to act as brokers (see below).

... what has given me most, maybe, is when we work with the competitions. And that's because it's when I meet other colleagues. I think that's one of the best ways to know that my knowledge is good or to improve it, is to meet another restaurant teacher from another restaurant programme somewhere in Sweden [...] and colleagues from the industry. (Chef and VET teacher) 


\section{Brokering of occupational knowledge}

The next type of boundary process is brokering of occupational knowledge from working life into the VET school. The brokers could be students, suppliers, or professionals who are brokering the vocational knowledge from current occupational practices into the practice of teaching the vocational subject. The main focus is students' learning, but the brokers also provide opportunities for VET teachers' learning.

\section{Students}

The first group of brokers are VET students who bring current occupational knowledge from their workplace-learning periods at workplaces into the school. The teachers take the opportunity to let students learn from each other, creating a broader imagination of current work-life practices based on their different experiences of workplace learning, and a side-effect is that these activities also create learning opportunities for the teacher.

\section{Visits from worksites and suppliers}

A second group of brokers are representatives from the specific industry who visit the VET school. They are invited to introduce certain forms of technology that they use, and their connected knowledge and skills, in areas where the teachers do not have the competence, and/or where the school is lacking this technology. Other visitors include suppliers of products used in the industry. They are willing to come to the school to present new products. The teachers take these opportunities of brokering the knowledge connected to the products, as alignment with and imagination of current technology is crucial for the teachers to be knowledgeable and up-to-date in the landscape of VET.

... they want to come and show their stuff, as it is these guys [the students] that should see it first. Because they are probably going to work with it in the future. (Plumber and VET teacher)

\section{Visits from experts}

The third group of brokers identified in the teachers' descriptions are the experts. When VET teachers have developed good networks in industry, they could take advantage of their connections with expert professionals and invite them to their schools. For example, the skills competitions described above give some teachers opportunities for such networking with experts. This also means imagination about and alignment with current practice, and possibly engaging in occupational activities with the experts.

... we [the teachers] have given them [the students] the starting point, but we as teachers learn a great deal too when he [an expert cook] comes here [our emphasis]. (Chef and VET teacher)

\section{Reconstructing the occupational practice at school}

We have described the teaching strategy of external contracts, involving students in authentic production of goods and services ordered by customers. In the earlier example, students and teachers engaged in work outside school. When the production takes place at school, this means a reconstruction of the occupational practice (Berner 2010). This type of activity is common in Swedish VET schools, with arrangements such as restaurants and hairdressing salons, offering boundary encounters with guests or customers from outside school. The strategy is employed as a school-based way for students to learn. But a possible consequence of the demand for quality and delivery to an authentic customer is that even the teacher is engaged in production, which means an opportunity for retaining and developing competence. Our example comes from CNC machinist training: 


\section{Learning and updating of occupational identity}

In what ways can the boundary processes enable VET teachers' learning of an up-to-date occupational identity? We have identified a number of different types of process - boundary encounters, brokering, and finally reconstruction - which offer opportunities for learning and up-dating of VET teachers' occupational identity related to the vocational subject in which they teach and train the students. The focus here is thus one side of the double identity of VET teachers, the occupational side, and learning related to this. But for these teachers, learning and identity formation are part of their daily work and life. In their stories, we see how activities that are part of the daily work as a VET teacher offer plenty of opportunities for learning, where teaching and initial occupation are intertwined.

Typically, the teachers develop a nexus of identities, the VET teacher identity. They are working as teachers, but through learning at work they develop not only teacher knowledge and identity, but also occupational knowledge and identity related to their initial occupations - and the vocational subject.

Some exceptions might arise where the VET teacher does things outside the teacher position that are solely occupation-related, but typically the two sides of the identity are closely related. Different types of boundary encounter between school and industry enable identification through imagination, alignment, and even engagement in occupational practices. Brokers provide occupationrelated learning opportunities at school, with learning in terms of imagination and alignment. Reconstruction of work-life practices at school also means a higher degree of authenticity for the teacher, who could be engaged in authentic work tasks with external contracts.

Some VET teachers describe problems or restrictions with worksite visits in relation to learning opportunities. One restriction is that visits do not mean engagement, which - at least in some occupations - is necessary for keeping skills alive.

It's not really a development of skills for me. I walk around, talk to the CNC machinists, check what the students have done, and also pick up new things for myself. That's how it is. But not enough really! [...] To keep this skill, ... you lose it, because skills must be kept alive ... you need to work with your hands. (CNC machinist and VET teacher)

Another problem is when the school organises the work with students' workplace learning in a way that does not give VET teachers a good opportunity for visits and imagination within their own vocational area:

... it's terrible when they have changed this organisation now, so I just go to the hospital and the elderly care facility, and for the other parts there are others who do it, and our part of the workplace visits has been shrinking a lot [...] - and this is a very important opportunity for my professional development. (Nurse and VET teacher no. 2)

\section{Influencing vocational teaching}

What influences do these boundary processes have on vocational teaching? The interplay between the VET teacher and working life influences not only the occupational identity but also the teacher identity and the teaching.

There is direct influence in activities where both students and teachers are involved. When the VET teacher is visiting students during workplace-learning periods, this is part of the teaching, and the meetings are potential learning opportunities for both teacher and student. We have also described a number of boundary processes in activities that are not necessarily part of VET teaching but if so, they are potential learning opportunities for both teacher and student. These processes include authentic work tasks obtained through external contracts, participation in skills competitions, brokers visiting the school, and reconstruction of the work-life practice at school. When part of teaching, all these activities offer the students opportunities for imagination and alignment through 
workplace learning, competitions, external brokers, and not least engagement through participation in workplaces, and reconstruction at school. However, it should be noted that the engagement in reconstructed work in a workshop at school does not include interaction with workers at a worksite. Instead, teachers and students act and interact as foremen and colleagues in the reconstructed practice.

Visits by VET teachers to workplaces could also influence the supervisors, who are part of the teaching and learning practice. These visits could help supervisors to develop an alignment with VET requirements and expectations, and a deeper engagement in students' learning processes, and through the visits influence the quality of workplace learning for students.

The teachers also take part in other boundary processes with a more indirect influence on teaching, when the main focus is occupational competence and identity. There are exceptions like the example above from the baker and pastry cook, who describes industry arrangements that include topics related to both teaching and occupation. One VET teacher also highlights how even occupation-related arrangements could have a direct influence, when he sees presentations and other types of material to be used directly in his lessons when he comes back to the teaching practice:

And then you always get materials from all the seminars, so you have to be on your toes and follow and make notes and so on. Then you get the PowerPoints from every lecture. I use those very often in my teaching ... (Electrician and VET teacher)

Our description and analysis of examples might give the impression that it is mainly single activities that are important in the relationship with VET teaching. However, the analysis also shows a broader and more complex pattern, where teachers' different ways of developing skills, knowledge, and identity mean better conditions for doing the job as a VET teacher - and thus influence their teaching. Teachers' relationships with the occupational practices are most important. Networking with colleagues from industry, workplace learning, interaction with brokers - all this helps teachers to develop their VET teacher identities and teaching processes, including the involvement of brokers in teaching.

\section{Discussion}

The aim of this study was to examine the interplay between school and working life, and how this may involve VET teachers and their updating of occupational competence and re-shaping of the VET teacher identity. The study has increased knowledge about boundary processes occurring between schools and workplaces. The findings described how different forms of processes provide opportunities for VET teachers' identification, learning and development of teaching for currency and alignment with the working life of today. Furthermore, the findings showed how the conditions for boundary crossings and learning are experienced by VET teachers. Considering the conditions for CPD among VET teachers, it is crucial to recognise their multi-membership as well as their dual and hybridised identity (Farnsworth and Higham 2012; Fejes and Köpsén 2014). In this article, we have developed the findings from Köpsén and Andersson (2018) about how the practice of teaching could include or exclude boundary processes with their former occupational practices and how the boundary processes, depending on different ways of enactment, enable different modes of VET teachers' identification and learning. Thus, such processes are important for the continuing occupational identity formation of VET teachers, but also for their teaching.

Students' workplace learning is one such important boundary process that is part of the teacher's work (Köpsén and Andersson 2018). However, VET teachers are involved in many boundary processes, and they initiate processes where students and guests act as brokers between industry and school. However, the teachers are not always aware of the potential for their own professional development that is inherent in boundary processes. Making them aware of this potential would 
mean better conditions for them to influence their own learning - to update their occupational identity and improve the currency in the content of VET teaching.

Offering opportunities for brokering is important both for the worksite and for the school to develop learning opportunities - for students, teachers, and employees at the worksites. In this study, the focus is on learning and identity formation among VET teachers, and what this means for their teaching - which is about learning opportunities for students. VET teachers' boundary crossings from school to worksite, and back again, are a basis for imagination and brokering of knowledge from the worksite into the school. For this to be fruitful, the teacher must be trusted in the worksite which gives the teacher access to relevant practices. Furthermore, there is a need for the teachers work to be organised in a way that allows for boundary processes (Köpsén and Andersson 2018) where teachers visit worksites, and participate in work, and where VET schools open up their boundaries for external brokers.

We have described what takes place among VET teachers, according to their stories. CPD as part of daily work is the dominant theme. However, this is not to say that VET teachers do not need organised CPD initiatives, but rather that this seems to be rare in Swedish VET. This means that VET teachers' CPD depends on individual initiatives and drivers (Andersson, Hellgren, and Köpsén 2018), rather than being part of a strategy for the institution. A strategy for developing VET teachers' CPD should include the responsibility of the institution to organise learning at work as well as CPD activities, but also to encourage individual initiatives and a passion for the occupation (Broad 2013). These initiatives should take place within and not outside working hours, to avoid the risk of huge personal contributions (Vähäsantanen, Saarinen, and Eleläpelto 2009). The VET programmes cover a broad spectrum of occupations, with their own landscapes of practice, networks, learning needs, and traditions. A strategy that allows for professional development aiming towards competence and knowledgeability in a variety of landscapes should support and trust the professional vocational teachers.

It is also important for the quality of CPD to include and integrate the different modes of identification that we have analysed. These modes mean different forms of participation, and CPD opportunities must allow for updating of different aspects of the occupational identity. Boundary processes including imagination and alignment might be enough for updating broader knowledgeability, while engagement in authentic work tasks could be necessary to retain and update the specific occupational identity and competence of qualified work. If not all these modes of identification are available to teachers, VET teaching will not be developed to keep its industrial currency. Thus, it is also important that employers take responsibility for these processes. In times of technological changes, VET teachers need continuing opportunities to engage in authentic work tasks as part of their CPD, and worksites must open up for such engagement.

\section{Disclosure statement}

No potential conflict of interest was reported by the authors.

\section{Funding}

This work was supported by the Swedish Research Council under [Grant 721-2013-2378].

\section{Notes on contributors}

Per Andersson is a professor of education at the Department of Behavioural Sciences and Learning at Linköping University, Sweden. His research interests focus on recognition of prior learning, professional development among teachers in vocational and adult education, and marketisation of adult education.

Susanne Köpsén is an associate professor of education at the Department of Behavioural Sciences and Learning at Linköping University, Sweden. Her research interests focus on teacher identity and the continuing professional development of vocational teachers. 


\section{ORCID}

Per Andersson (iD) http://orcid.org/0000-0003-1194-9708

\section{References}

Akkerman, S., and T. Bruining. 2016. "Multilevel Boundary Crossing in a Professional Development School Partnership." Journal of the Learning Sciences 25 (2): 240-284. doi:10.1080/10508406.2016.1147448.

Andersson, P., M. Hellgren, and S. Köpsén. 2018. "Factors Influencing the Value of CPD Activities among VET Teachers." International Journal for Research in Vocational Education and Training 5 (2): 140-164. doi:10.13152/IJRVET.5.2.4

Andersson, P., and S. Köpsén. 2015. "Continuing Professional Development of Vocational Teachers: Participation in a Swedish National Initiative." Empirical Research in Vocational Education and Training 7 (7): 1-20. doi:10.1186/ s40461-015-0019-3.

Andersson, P., and S. Köpsén. 2018. "Maintaining Competence in the Initial Occupation: Activities among Vocational Teachers." Vocations and Learning 11 (2): 317-344. doi:10.1007/s12186-017-9192-9.

Berner, B. 2010. "Crossing Boundaries and Maintaining Differences between School and Industry: Forms of Boundary Work in Swedish Vocational Education." Journal of Education and Work 23 (1): 27-42. doi:10.1080/ 13639080903461865.

Bound, H. 2011. "Vocational Education and Training Teacher Professional Development: Tensions and Context." Studies in Continuing Education 33 (2): 107-119. doi:10.1080/0158037X.2011.554176.

Brennan Kemmis, R., and A. Green. 2013. "Vocational Education and Training Teachers' Conceptions of Their Pedagogy." International Journal of Training Research 11 (2): 101-121. doi:10.5172/ijtr.2013.11.2.101.

Broad, J. H. 2013. Doing it for Themselves: A Network Analysis of Vocational Teachers' Development of their Occupationally Specific Expertise. EdD thesis. London: Institute of Education, University of London.

Broad, J. H. 2015. "So Many Worlds, so Much to Do: Identifying Barriers to Engagement with Continued Professional Development for Teachers in the Further Education and Training Sector." London Review of Education 13 (1): 16-30. doi:10.18546/LRE.13.1.03.

Broad, J. H. 2016. "Vocational Knowledge in Motion: Rethinking Vocational Knowledge through Vocational Teachers' Professional Development." Journal of Vocational Education \& Training 68 (2): 143-160. doi:10.1080/ 13636820.2015.1128962.

Cedefop. 2009. Modernising Vocational Education and Training, Fourth Report on Vocational Education and Training Research in Europe: Synthesis report. Luxembourg: Publications Office of the European Union.

Cedefop. 2018a. The Changing Nature and Role of Vocational Education and Training in Europe. Volume 3: The Responsiveness of European VET Systems to External Change (1995-2015). Cedefop research paper; No 67. Luxembourg: Publications Office of the European Union.

Cedefop. 2018b. VET-in-Europe Country Reports. Accessed 28 December 2018. http://www.cedefop.europa.eu/en/pub lications-and-resources/country-reports/vet-in-europe-country-reports

Deissinger, T., J. Aff, A. Fuller, and C. H. Jørgensen, Eds. 2013. Hybrid Qualifications: Structures and Problems in the Context of European VET Policy. Bern: Peter Lang.

Dobbins, M., and M. R. Busemeyer. 2015. "Socio-Economic Institutions, Organized Interests and Partisan Politics: The Development of Vocational Education in Denmark and Sweden." Socio-Economic Review 13 (2): $259-284$. doi:10.1093/ser/mwu002.

Farnsworth, V., and J. Higham. 2012. "Teachers Who Teach Their Practice: The Modulation of Hybridised Professional Teacher Identities in Work-Related Educational Programmes in Canada." Journal of Education and Work 25 (4): 473-505. doi:10.1080/13639080.2012.708726.

Farnsworth, V., I. Kleanthous, and E. Wenger-Trayner. 2016. "Communities of Practice as A Social Theory of Learning: A Conversation with Etienne Wenger." British Journal of Educational Studies 64 (2): 139-160. doi:10.1080/ 00071005.2015.1133799.

Fejes, A., and S. Köpsén. 2014. "Vocational Teachers' Identity Formation through Boundary Crossing." Journal of Education and Work 27 (3): 265-283. doi:10.1080/13639080.2012.742181.

Frisk, T. 2014. Guide for the Implementation of Vocational Teachers' Work Placement Periods. Helsinki: Finnish National Board of Education.

Köpsén, S. 2014. "How Vocational Teachers Describe Their Vocational Teacher Identity." Journal of Vocational Education \& Training 66 (2): 194-211. doi:10.1080/13636820.2014.894554.

Köpsén, S., and P. Andersson. 2017. "Reformation of VET and Demands on Teachers' Subject Knowledge: Swedish Vocational Teachers' Recurrent Participation in a National CPD Initiative." Journal of Education and Work 30 (1): $69-83$. doi:10.1080/13639080.2015.1119259.

Köpsén, S., and P. Andersson. 2018. "Boundary Processes in Connection with Students' Workplace Learning: Potentials for VET Teachers' Continuing Professional Development." Nordic Journal of Vocational Education and Training 8 (1): 58-75. doi:10.3384/njvet.2242-458X. 
Lave, J., and E. Wenger. 1991. Situated Learning: Legitimate Peripheral Participation. Cambridge: Cambridge University Press.

Lloyd, C., and J. Payne. 2012. "Raising the Quality of Vocational Teachers: Continuing Professional Development in England, Wales and Norway." Research Papers in Education 27 (1): 1-18. doi:10.1080/02671522.2010.483524.

Messmann, G., and R. H. Mulder. 2011. "Innovative Work Behaviour in Vocational Colleges: Understanding How and Why Innovations are Developed." Vocations and Learning 4 (1): 63-84. doi:10.1007/s12186-010-9049-y.

Parsons, D., J. Huges, C. Allincon, and K. Walsh. 2009. "The Training and Development of VET Teachers and Trainers in Europe" In Cedefop Modernising Vocational Education and Training, Fourth Report on Vocational Education and Training Research in Europe: Synthesis Report. Luxembourg: Publications Office of the European Union.

Robson, J., B. Bailey, and S. Larkin. 2004. "Adding Value: Investigating the Discourse of Professionalism Adopted by Vocational Teachers in Further Education Colleges." Journal of Education and Work 17 (2): 183-195. doi:10.1080/ 13639080410001677392.

Smith, E., and K. Yasukawa. 2017. "What Makes a Good VET Teacher? Views of Australian VET Teachers and Students." International Journal of Training Research 15 (1): 23-40. doi:10.1080/14480220.2017.1355301.

Swedish National Agency for Education. 2017. Personal i gymnasieskolan läsår 2016/17 [Staff in upper secondary school year 2016/17]. Tabell 5A. Accessed 19 October 2017. https://www.skolverket.se/statistik-och-utvardering/statistik-itabeller/gymnasieskola/personal

Swedish Research Council. 2017. Good Research Practice. Stockholm: Swedish Research Council.

Tanggaard, L. 2007. "Learning at Trade Vocational School and Learning at Work: Boundary Crossing in Apprentices' Everyday Life." Journal of Education and Work 20 (5): 453-466. doi:10.1080/13639080701814414.

Vähäsantanen, K., and A. Eteläpelto. 2009. "Vocational Teachers in the Face of a Major Educational Reform: Individual Ways of Negotiating Professional Identities." Journal of Education and Work 22 (1): 15-33. doi:10.1080/ 13639080802709620.

Vähäsantanen, K., J. Saarinen, and A. Eteläpelto. 2009. "Between School and Working Life: Vocational Teachers' Agency in Boundary-Crossing Settings." International Journal of Educational Research 48: 395-404. doi:10.1016/j. ijer.2010.04.003.

Wenger, E. 1998. Communities of Practice: Learning, Meaning, and Identity. Cambridge: Cambridge University Press.

Wenger-Trayner, E., and B. Wenger-Trayner. 2015. "Learning in a Landscape of Practice: A Framework." In Learning in Landscapes of Practice: Boundaries, Identity, and Knowledgeability in Practice-Based Learning, edited by E. WengerTrayner, M. Fenton-O'Creevy, S. Hutchinson, C. Kubiak, and B. Wenger-Trayner, 13-29. Abingdon: Routledge. 